Scientia Agricola

http://dx.doi.org/10.1590/0103-9016-2014-0221

\title{
Histochemical aspects of wheat resistance to leaf blast mediated by silicon
}

\author{
Washington Luís da Silva, Maria Fernanda Antunes Cruz, Alessandro Antônio Fortunato, Fabrício Ávila Rodrigues*
}

Federal University of Viçosa - Dept. of Plant Pathology, Lab. of Host-Parasite Interaction, Av. Peter Henry Rolfs, s/n36570-900 - Viçosa, MG - Brazil.

*Corresponding author<fabricio@ufv.br>

Edited by: Luís Eduardo Aranha Camargo

Received June 26, 2014

Accepted December 21, 2014
ABSTRACT: Blast, caused by Pyricularia oryzae, has become a significant disease threat to wheat (Triticum aestivum L.) in Brazil. This study aimed to investigate at the histochemical level if silicon (Si) could enhance the production of flavonoids in the leaves of wheat plants in response to $P$. oryzae infection. Plants from the Aliança cultivar, which are susceptible to blast, were grown in hydroponic cultures containing $0(-\mathrm{Si})$ or $2 \mathrm{mM}$ of $\mathrm{Si}(+\mathrm{Si})$ and inoculated by spraying a conidial suspension of $P$. oryzae $\left(1 \times 10^{5}\right.$ conidia $\left.\mathrm{mL}^{-1}\right)$ on all adaxial leaf surfaces of plants at 60 days after emergence (growth stage 65 ). The fourth and fifth leaves of each plant were used to evaluate blast severity at 24, 36, 48, 72 and $96 \mathrm{~h}$ after inoculation (hai). At 96 hai, leaves were collected from plants to determine the foliar Si concentration. For cytological observations, leaf samples were randomly collected from the fourth and fifth leaves of each plant at 72 hai. The foliar Si concentration was higher in +Si plants $\left(36 \mathrm{~g} \mathrm{~kg}^{-1}\right)$ in comparison to -Si plants (2.6 $\left.\mathrm{g} \mathrm{kg}^{-1}\right)$. This increased $\mathrm{Si}$ concentration was correlated with reduced fungal growth inside the epidermal cells and the development of blast symptoms on leaves. Strong fluorescence, which is an indication of the presence of flavonoids, was detected in the leaf cells of +Si plants using Neu's and Wilson's reagents. A novel item of evidence is that, at the histochemical level, $\mathrm{Si}$ is involved in the potentiation of the biosynthetic pathway of flavonoids that increases wheat resistance to blast.

Keywords: Pyricularia oryzae, flavonoids, histochemistry, phenolics

\section{Introduction}

Blast, caused by the fungus Pyricularia oryzae Sacc. (teleomorph Magnaporthe grisea (Hebert) Barr), has limited wheat (Triticum aestivum L.) production in Brazil and in other South American countries (Igarashi et al., 1986; Goulart and Paiva, 1992). The occurrence of graybrown lesions on wheat spikes and spikelets contributes to decreased yield due to a reduction in the translocation of nutrients to the grains (Goulart et al., 2007).

Blast symptoms on wheat leaves are gray-green and water-soaked lesions with dark green borders (Goulart et al., 2007). Blast has been considered of economic importance in locations where it has occurred due to the intensity of the symptoms, mainly in the ear, that cause great yield losses (Goulart et al., 2007). Moreover, the main strategies adopted to manage blast are not efficient, including fungicide spraying. Due to these concerns, it is necessary to find alternative methods for blast control that will reduce wheat losses caused by blast.

Silicon (Si) has been effective in reducing the intensity of disease in economically important crops such as barley (Hordeum vulgare), corn (Zea mays), cucumber (Cucumis sativus), grape (Vitis vinifera), rice (Oryza sativa), ryegrass (Lolium spp.), sorghum (Sorghum bicolor) and soybean (Glycine max) (Datnoff et al., 2007). Application of $\mathrm{Si}$ can increase wheat resistance to powdery mildew (Bélanger et al., 2003; Rémus-Borel et al., 2005; Guével et al., 2007), leaf streak (Silva et al., 2010), spot blotch (Domiciano et al., 2010) and leaf blast (Xavier Filha et al., 2011; Pagani et al., 2014). The Siincreased resistance of plants can be attributed to the deposition of amorphous silica in leaves, which prevents or delays fungal penetration of the epidermal cells or to an increased concentration of phenolics, lignin and phytoalexins, as well as rapid and strong activation of certain pathogenesis-related genes (Datnoff et al., 1997).

Phenolic compounds are secondary plant metabolites that arise biogenetically from the shikimatephenylpropanoids-flavonoids pathways (Lattanzio et al., 2006). An increase in the concentration of phenolics during the infection process of many pathogens plays a pivotal role in host defense (Nicholson and Hammerschmidt, 1992). In histological and ultrastructural analyses, Bélanger et al. (2003) found that the greatest cytochemical difference between wheat plants supplied and non-supplied with Si was the extensive deposition of glycosilated phenolics, as determined by cytochemical labeling, in the cell wall of infected epidermal cells of Si-treated plants and on the extra-haustorial membrane of Blumeria graminis f.sp. tritici.

This study aimed to investigate, at the histochemical level, whether Si could enhance the production of flavonoids in leaves of wheat plants, and if so, whether this increased flavonoid production would reduce blast symptoms on leaves.

\section{Materials and Methods}

A modified Hoagland and Arnon (1950) nutrient solution was prepared with the following macronutrients and micronutrients: $1.0 \mathrm{mM} \mathrm{KNO}_{3}, 0.25$ $\mathrm{mM} \mathrm{NH}_{4} \mathrm{H}_{2} \mathrm{PO}_{4}, 0.1 \mathrm{mM} \mathrm{NH}_{4} \mathrm{Cl}, 0.5 \mathrm{mM} \mathrm{MgSO}{ }_{4} .7 \mathrm{H}_{2} \mathrm{O}$, $1.0 \mathrm{mM} \mathrm{Ca}\left(\mathrm{NO}_{3}\right)_{2} \cdot 4 \mathrm{H}_{2} \mathrm{O}, 0.30 \mu \mathrm{M} \mathrm{CuSO}_{4} .5 \mathrm{H}_{2} \mathrm{O}, 0.33 \mu \mathrm{M}$ $\mathrm{ZnSO}_{4} .7 \mathrm{H}_{2} \mathrm{O}, 11.5 \mu \mathrm{M} \mathrm{H}_{3} \mathrm{BO}_{3}, 3.5 \mu \mathrm{M} \mathrm{MnCl}{ }_{2} .4 \mathrm{H}_{2} \mathrm{O}, 0.1$ 
$\mu \mathrm{M}\left(\mathrm{NH}_{4}\right) \cdot 6 \mathrm{Mo}_{7} \mathrm{O}_{2} \cdot 4 \mathrm{H}_{2} \mathrm{O}, 25 \mu \mathrm{M} \mathrm{FeSO} \mathrm{H}_{4} \cdot 7 \mathrm{H}_{2} \mathrm{O}$ and $25 \mu \mathrm{M}$ disodium EDTA. Silicon was supplied as monosilicic acid, which was prepared by passing potassium silicate through cation-exchange resin (Ma et al., 2002). The Si concentrations used were either 0 or $2 \mathrm{mM}$. The addition of monosilicic acid to the nutrient solution did not alter the $\mathrm{pH}$.

Wheat seeds from the Aliança cultivar, which are susceptible to $P$. oryzae infection, were surface sterilized in $10 \%(\mathrm{v} / \mathrm{v}) \mathrm{NaOCl}$ for $2 \mathrm{~min}$, rinsed in sterilized water for $3 \mathrm{~min}$ and germinated on distilled water-soaked germitest paper in a germination chamber at $25{ }^{\circ} \mathrm{C}$ for six days. Germinated seedlings were transferred to plastic containers containing a half-strength nutrient solution without Si for a period of two days. After this period, plants were transferred to new plastic containers supplied with nutrient solution with or without Si. The nutrient solution, which was aerated, was changed every four days while the $\mathrm{pH}$ was checked daily and maintained at approximately 5.5 by using $\mathrm{NaOH}$ or $\mathrm{HCl}$ (1 M) when needed.

A pathogenic isolate of $P$. oryzae (UFV/DFP Po-01) obtained from the spikes of wheat plants from the BR-18 cultivar were used to inoculate the plants (Debona et al., 2012). Filter paper discs containing fungal mycelia were transferred to Petri dishes containing oat-agar medium. After cultivating the disks, the media with the fungus were transferred to new Petri dishes containing the same medium. The dishes were incubated in a growth chamber at $25^{\circ} \mathrm{C}$ with a $24 \mathrm{~h}$ photoperiod for 10 days. Following this incubation, conidia were removed from the Petri dishes with a soft bristle brush and water containing 1 $\%(\mathrm{w} / \mathrm{v})$ gelatin. The conidial suspension was calibrated with a hemacytometer to obtain a concentration of $1 \times$ $10^{5}$ conidia $\mathrm{mL}^{-1}$.

The conidial suspension was sprayed with an atomizer on all adaxial leaf surfaces of wheat plants 60 days after emergence (growth stage 65) (Zadoks et al., 1974). Immediately after inoculation, the plants were transferred to a growth chamber with a temperature of $25 \pm 2{ }^{\circ} \mathrm{C}$ and relative humidity of $90 \pm 5 \%$ and were subjected to an initial 24-h dark period. After this period, the plants were transferred to a plastic mist growth chamber (MGC) inside a greenhouse for the duration of the experiment. The MGC was made of wood $(2 \mathrm{~m}$ wide, $1.5 \mathrm{~m}$ high and $5 \mathrm{~m}$ long) and covered with $100-\mu \mathrm{m}$-thick transparent plastic. The temperature inside the MGC ranged from $25 \pm 2{ }^{\circ} \mathrm{C}$ (day) to $20 \pm 2{ }^{\circ} \mathrm{C}$ (night). The relative humidity was maintained at $92 \pm 3 \%$ using a misting system in which nozzles sprayed mist above the plant canopy every $30 \mathrm{~min}$. The relative humidity and temperature were measured with a thermo-hygrograph. The maximum natural photon flux density at the plant canopy height was approximately $900 \mu \mathrm{mol} \mathrm{m} \mathrm{m}^{-2} \mathrm{~s}^{-1}$.

The fourth and fifth leaves, from the base to the apex, of each plant per replication of each treatment were marked and used to evaluate blast severity at 24 , $36,48,72$ and $96 \mathrm{~h}$ after inoculation (hai) using the scale proposed by Rios et al. (2013). The area under blast progress curve (AUBPC) for each leaf was computed using a trapezoidal integration of the blast progress curve over time according to the method described by Shaner and Finney (1977).

At the end of the experiment, leaves collected from plants of each replication per treatment were washed in deionized water, dried for $72 \mathrm{~h}$ at $65^{\circ} \mathrm{C}$ and ground to pass through a 40-mesh screen with a Thomas Wiley mill. The foliar Si concentration was determined by colorimetric analysis of $0.1 \mathrm{~g}$ dried and alkali-digested tissue (Domiciano et al., 2010).

A total of 10 to 15 leaf pieces $\left(\approx 0.5 \mathrm{~cm}^{2}\right.$ in size), containing individual infection sites, were randomly collected from the leaves of each plant per treatment at 96 hai. Leaf samples were transferred to glass vials containing $10 \mathrm{~mL}$ of fixative composed of $2.5 \%$ (vol/ vol) glutaraldehyde in $0.1 \mathrm{M}$ sodium cacodylate buffer $(\mathrm{pH} 7.2)$ and stored at $4{ }^{\circ} \mathrm{C}$ for five days. Leaf samples from all treatments were carefully washed with sodium cacodylate buffer followed by distilled water and then dried on a piece of paper. Then, the adaxial leaf epidermis of each specimen was mounted onto aluminum stubs and coated with gold and palladium to give conductivity to the specimens. Specimens were examined under a CAMECA SX-100 Universal EPMA scanning electron microscope with an energy dispersive X-ray microanalysis mapping operating at $15 \mathrm{kV}$ and 20 $\mathrm{nA}$. At least six images were obtained from each leaf fragment per treatment.

For the cytological observations, a total of 80-100 leaf samples $\left(\approx 0.5 \mathrm{~cm}^{2}\right.$ in size) were randomly collected from fourth and fifth leaves, from the base to the apex, of each plant per replication of each treatment at 72 hai. Leaf samples were fixed and decolorized in boiling $95 \%$ ethanol (vol/vol) for $15 \mathrm{~min}$ and then cleared for three weeks in a saturated chloral hydrate solution (100 g $\left.\mathrm{mL}^{-1}\right)$. Cleared leaf samples were mounted adaxial-sideup on glass slides containing three drops of modified Hoyer's mounting medium (Rodrigues et al., 2005).

Fifty randomly selected appressorial sites per replication of each treatment were examined in detail to assess fungal growth inside epidermal cells using an Axio Imager A1 microscope equipped with differential interference contrast optics. The autofluorescence of the epidermal cell walls or the whole epidermal cells of each appressorial site examined was recognized by fluorescence microscopy using Zeiss filter set 13 (470 nm excitation, $495 \mathrm{~nm}$ beam splitter and 505-530 nm emission). All digital images were taken with an AxioCam HRc Rev. 2 and further processed with the AxioVision 4.6 software.

Six leaf samples $\left(\approx 0.5 \mathrm{~cm}^{2}\right.$ in size) were collected from one plant per replication of each treatment at 72 hai for histochemical staining of the phenylpropanoid derivatives in each leaf section. Leaf samples were also collected from non-inoculated plants at 0 dai to serve as controls. The leaf samples were placed in plastic tubes 
containing $50 \mathrm{~mL}$ of $50 \mathrm{mM}$ potassium phosphate buffer $(\mathrm{pH}$ 6.5), covered with aluminum foil and stored at -20 ${ }^{\circ} \mathrm{C}$ for further analysis.

A total of thirty handmade transverse sections 140 to $60 \mu \mathrm{m}$ thick) per leaf sample was obtained from leaves of both non-inoculated and inoculated plants using a scalpel blade. Flavonoids were visualized using Neu's reagent (Fortunato et al., 2012). A total of six sections were immersed in a solution consisting of $1 \% 2$-aminoethyldiphenyl-borinate dissolved in absolute methanol for $5 \mathrm{~min}$ and then mounted on glass slides with two drops of a glycerine:water solution $(2: 8 \mathrm{v} / \mathrm{v})$.

Bright lemon-yellow fluorescence indicated the presence of flavonoids in the leaf tissue. Flavonoids were also detected using Wilson's reagent (Dai et al., 1995a, b). A total of six sections were immersed in a $0.01 \mathrm{M}$ solution of citric and boric acids dissolved in $100 \mathrm{~mL}$ of absolute methanol for $15 \mathrm{~min}$ and then mounted on glass slides with two drops of a glycerine:water solution. Yellow fluorescence indicated flavonoid presence in the leaf tissue. All of the transverse sections were examined using an Axio Imager A1 microscope with Zeiss filter sets 01 (UV; $365 \mathrm{~nm}$ excitation, $395 \mathrm{~nm}$ beam splitter and $397 \mathrm{~nm}$ emission) and 05 (blue; 395-400 $\mathrm{nm}$ excitation, $460 \mathrm{~nm}$ beam splitter and $470 \mathrm{~nm}$ emission). All digital images were acquired with an AxioCam HRc Rev. 2 and further processed with the AxioVision 4.6 software.

Two $2 \times 2$ factorial experiment, consisting of two $\mathrm{Si}$ concentrations $(0$ and $2 \mathrm{~m}$ hereafter referred to as the $-\mathrm{Si}$ and $+\mathrm{Si}$ plants, respectively) and noninoculated or inoculated plants, were arranged in a completely randomized design with 15 replications. Each experimental unit corresponded to a plastic pot containing five plants. A total of 300 plants were used in each experiment (15 plants per treatment at each evaluation time).

Data from foliar Si concentration and AUBPC of the two experiments were combined after determination of the homogeneity of variance by Cochran's test (Gomez and Gomez, 1994). Data from foliar Si concentration and AUBPC were subjected to an analysis of variance (ANOVA) and the means from each treatment were compared using an F-test ( $p \leq 0.05)$.

\section{Results and Discussion}

The foliar $\mathrm{Si}$ concentration was higher $(p=$ $0.012)$ in $+\mathrm{Si}$ plants $\left(36 \mathrm{~g} \mathrm{~kg}^{-1}\right)$ in comparison to the -Si plants $\left(2.6 \mathrm{~g} \mathrm{~kg}^{-1}\right)$. The foliar Si concentration had a similar trend across treatments based on a preliminary experiment (data not shown). X-ray microanalysis revealed a different pattern of $\mathrm{Si}$ deposition between the leaves of $-\mathrm{Si}$ and $+\mathrm{Si}$ plants (Figure 1). In + Si plants, Si was deposited in greater amounts and in a linear pattern that corresponded to silica cells in comparison to scarce Si deposition in the leaves of -Si plants (Figure 1).

By 72 hai, hyphae of $P$. oryzae had grown successfully and formed an extensively branched
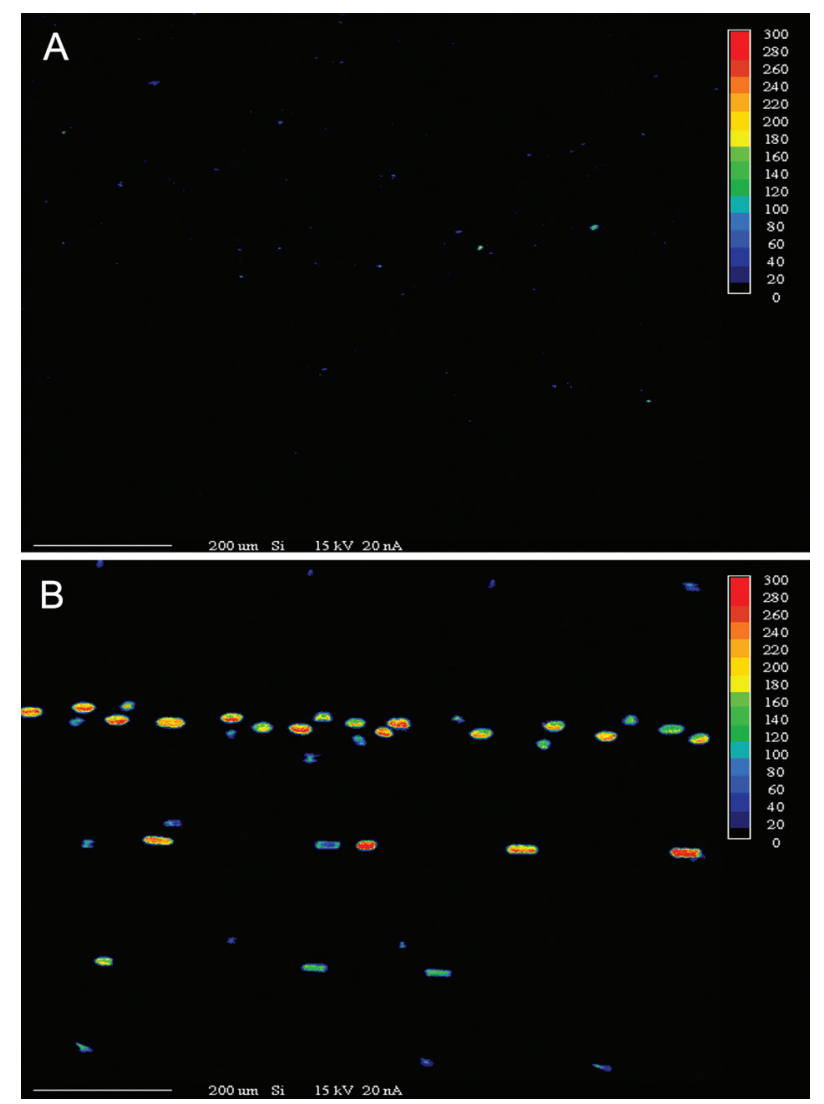

Figure 1 - Silicon deposition, as determined by X-ray microanalysis, in the adaxial surface of leaves of wheat plants grown in hydroponic culture containing 0 (A) or $2 \mathrm{mM}$ of silicon (Si) (B) at 96 hours after inoculation with Pyricularia oryzae. The red color indicates the highest level of Si deposition whereas black represents no deposition.

mycelium in the first-penetrated epidermal cell and invaded many neighboring cells in the leaves of -Si plants (Figure 2A). In contrast, fungal hyphae were restricted to the first-penetrated epidermal cell in $+\mathrm{Si}$ plants (Figure 2B). In -Si plants, autofluorescence was restricted to the cell wall of the penetrated epidermal cell and the cell wall of adjacent epidermal cells (Figure 2C), while in +Si plants, autofluorescence occurred inside the penetrated epidermal cell (Figure 2D). In + Si plants, the AUBPC was reduced $(p=0.016)$ by 35 $\%$ compared to -Si plants (876 and 569 for $-\mathrm{Si}$ and $+\mathrm{Si}$, respectively). Blast severity showed a similar trend across treatments based on a preliminary experiment (data not shown).

Strong fluorescence was detected in the epidermal and parenchyma cells as well as in the vascular vessels of the leaf sections of the -Si plants (Figure $3 \mathrm{~A}$ and $\mathrm{C}$ ) in contrast to the + Si plants (Figure $3 \mathrm{~B}$ and $\mathrm{D}$ ) after using Neu's (Figure 3A and B) and Wilson's (Figure 3C and D) reagents. There was no difference between the leaf sections of the $-\mathrm{Si}$ and $+\mathrm{Si}$ non-inoculated plants. 

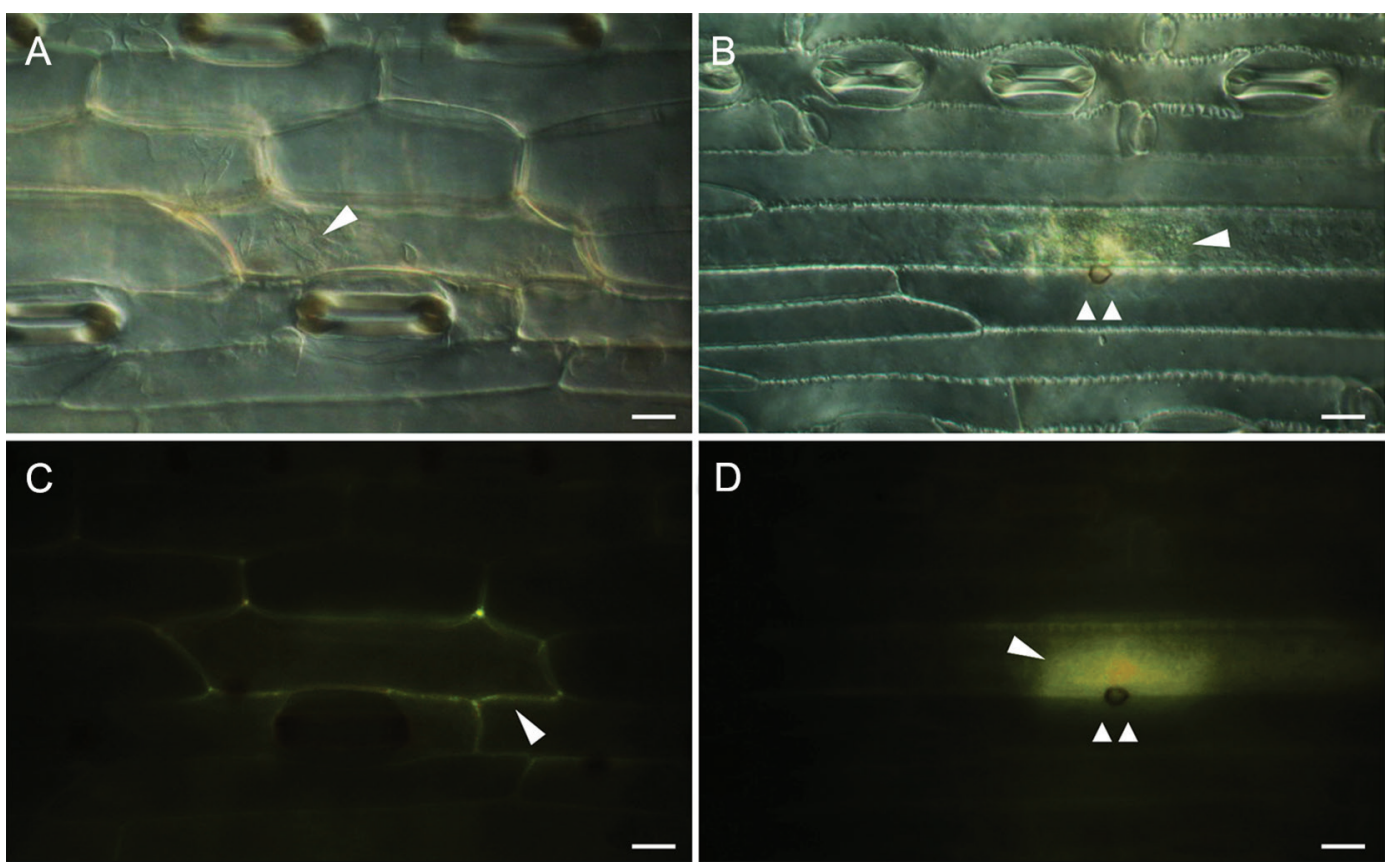

Figure 2 - Differential interference contrast microscopy of cleared epidermal cells in the adaxial surface of leaves of wheat plants grown in hydroponic culture containing 0 (-Si) (A and C) or $2 \mathrm{mM}(+\mathrm{Si})$ of silicon (B and D) at 72 hours after inoculation with Pyricularia oryzae. A) Welldeveloped hyphae of $P$. oryzae in the penetrated epidermal cell (arrowhead) produced several branches and colonized neighboring epidermal cells on a leaf from a -Si plant. B) Hyphae of $P$. oryzae (arrowhead) were restricted to the penetrated epidermal cell. C) Autofluorescence on the wall of the penetrated epidermal cell and in the cell wall of some adjacent epidermal cells (arrowhead) on a leaf from a -Si plant. D) Autofluorescence in the cytoplasm of the penetrated epidermal cell (arrowhead) on a leaf from a + Si plant. A, B, C and D = 400 $\times$ magnification. Apressorium (double arrows).

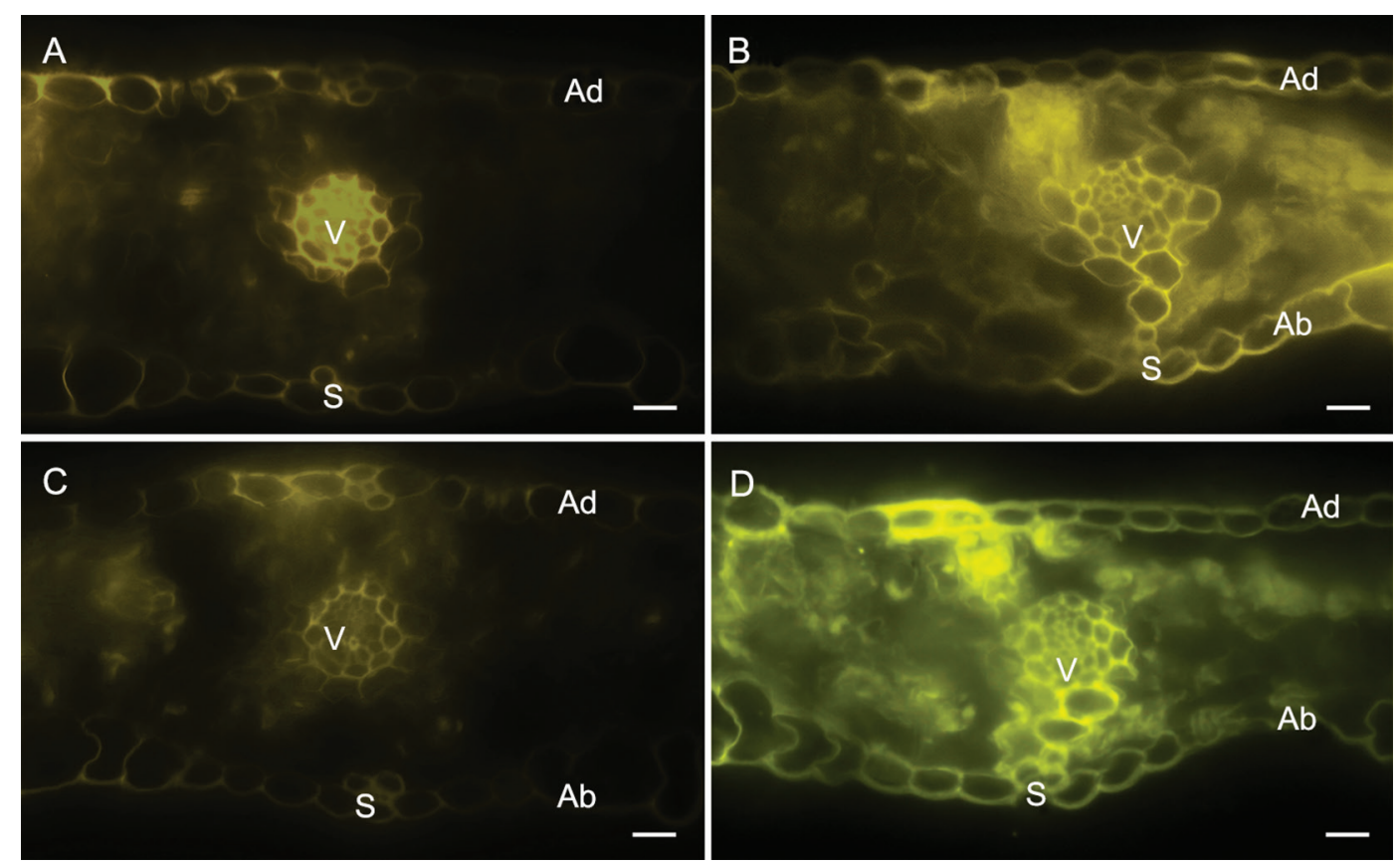

Figure 3 - Histochemical detection of flavonoids in transverse sections of leaves of wheat plants grown in hydroponic culture containing 0 (A and C) or $2 \mathrm{mM}$ of silicon (Si) (B and D) and inoculated with Pyricularia oryzae using Neu's ( $A$ and B) and Wilson's (C and D) reagents. Ad and Ab = adaxial and abaxial surfaces of the transverse sections, respectively. $\mathrm{V}$ and $\mathrm{s}=$ vascular vessel and stomata, respectively. 
The present study confirms that Si can increase wheat resistance to blast (Xavier Filha et al., 2011; Sousa et al., 2013) and, to the best of our knowledge, provides novel evidence at the histochemical level about the involvement of this element in the potentiation of the biosynthetic pathway of flavonoids in the leaves of wheat plants infected with $P$. oryzae.

Monocot plants are very efficient in accumulating and translocating Si from roots to leaves through the uptake of monosilicic acid from the soil and, therefore, become resistant to diseases such as blast in rice and wheat, anthracnose in sorghum and Fusarium wilt in banana (Rodrigues et al., 2005; Resende et al., 20012, Xavier Filha et al., 2011; Fortunato et al., 2012). The high foliar Si concentration contributed to a reduction in fungal growth inside the epidermal cells and, consequently, to reduced blast symptoms. This can be attributed to the presence of flavonoids, determined by Neu's and Wilson's reagents, which played a pivotal role in the increased resistance of wheat to blast.

Strong autofluorescence, which is indicative of the presence of phenolics (Rodrigues et al., 2005), was detected inside the epidermal cells of the leaves of + Si plants, but this autofluorescence was restricted to the walls of a few epidermal cells in the leaves of -Si plants. It is likely that these phenolics contributed to a reduction in fungal growth. The potentiation of the phenylpropanoid pathway in plants supplied with $\mathrm{Si}$ as a strategy to protect them against pathogen infection is very well documented in the literature (Koga et al., 1988; Rémus-Borel et al., 2005; Rodrigues et al., 2005, Fortunato et al., 2012). Rémus-Borel et al. (2005) also observed the presence of phenolic-like material associated with degraded haustoria of $B$. graminis f.sp. tritici on the leaves of wheat plants supplied with Si. In addition, thin-layer chromatography analyses coupled with a bioassay revealed the presence of fungitoxic aglycones in the plants supplied with $\mathrm{Si}$.

The application of $3.6 \mathrm{mM}$ Si to rose plants increased the concentration of antimicrobial phenolic acids and flavonoids in response to infection by Podosphaera pannosa (Shetty et al., 2011). Simultaneously, the expression of genes coding key enzymes in the phenylpropanoid pathway (phenylalanine ammonia lyase, cinnamyl alcohol dehydrogenase and chalcone synthase) was up-regulated in rose plants supplied with Si contributing, therefore, to a reduction in the powdery mildew severity (Shetty et al., 2011). Rodrigues et al. (2003) provided the first cytological evidence that Si-mediated resistance to $P$. oryzae infection in rice leaves correlated with a specific leaf cell reaction that interfered with fungal development.

Accumulation of an amorphous material that reduced the extent of fungal colonization was a typical feature of cells reaction in response to infection by $P$. oryzae in leaves of $+\mathrm{Si}$ plants. The occurrence of empty fungal hyphae, surrounded or trapped in amorphous material in rice leaf samples from + Si plants, suggests that phenolic-like compounds or phytoalexins played a primary role in the rice defense response against infection by P. oryzae (Rodrigues et al., 2003). In another study, Rodrigues et al. (2004) reported higher levels of momilactone phytoalexins in leaf extracts obtained from plants inoculated with $P$. oryzae and supplied with $\mathrm{Si}$. The deposition of flavonoids in plant cell walls is a strong biochemical defense in response to pathogen infection (Lattanzio et al., 2006). Microscopic observations reported by Rémus-Borel et al. (2005) revealed that wheat plants supplied with Si showed fluorescence of phenolics in response to infection by Blumeria graminis f.sp. tritici. Valette et al. (1998) detected the deposition of flavonoids in the cell walls of the roots of a partially resistant banana cultivar infected by Radopholus similis.

The results of the present study support the notion that wheat resistance to blast was potentiated by $\mathrm{Si}$ and the phenylpropanoid pathway played a pivotal role in this scenario.

\section{Acknowledgments}

Prof. F.A. Rodrigues would like to thank the Brazilian National Council for Scientific and Technological Development (CNPq) for his fellowship. Dra. Maria F.A. Cruz was supported by the Minas Gerais State Foundation for Research Support (FAPEMIG). This study was supported by grants from Coordination for the Improvement of Higher Level Personnel (CAPES), FAPEMIG and $\mathrm{CNPq}$ organizations to Prof. F.A. Rodrigues.

\section{References}

Bélanger, R.R.; Benhamou, N.; Menzies, J.G. 2003. Cytological evidence of an active role of silicon in wheat resistance to powdery mildew (Blumeria graminis f.sp. tritici). Phytopathology 93: 402-412.

Dai, G.H.; Andary, C.; Mondolot-Cosson, L.; Boubals, D. 1995a. Histochemical responses of leaves of in vitro plantlets of Vitis spp. to infection with Plasmopara viticola. Phytopathology 85: 149-154.

Dai, G.H.; Andary, C.; Mondolot-Cosson, L.; Boubals, D. 1995b. Histochemical studies on the interaction between three species of grapevine, Vitis vinifera, V. rupestris and V. rotundifolia and the downy mildew fungus, Plasmopara viticola. Physiological and Molecular Plant Pathology 46: 177-188.

Datnoff, L.E.; Rodrigues, F.A.; Seebold, K.W. 2007. Silicon and plant disease. p. 233-246. In: Datnoff, L.E.; Elmer, W.H.; Huber, D.M., eds. Mineral nutrition and plant disease. APS Press, St Paul, MN, USA.

Debona, D.; Rodrigues, F.A.; Rios, J.A.; Telles, K.J.N. 2012. Biochemical changes in the leaves of wheat plants infected by Pyricularia oryzae. Phytopathology 102: 1121-1129.

Domiciano, G.P.; Rodrigues, F.A.; Vale, F.X.R.; Xavier Filha, M.S.; Moreira, W.R.; Andrade, C.C.L.; Pereira, S.C. 2010. Wheat resistance spot blotch potentiated by silicon. Journal of Phytopathology 158: 334-343. 
Fortunato, A.A.; Rodrigues, F.A.; Nascimento, K.J.T. 2012. Physiological and biochemical aspects of the resistance of banana plants to Fusarium wilt potentiated by silicon. Phytopathology 102: 957-966.

Gomez, K.A.; Gomez, A.A. 1994. Statistical Procedures for Agricultural Research. 2 ed., John Wiley, New York, NY, USA.

Goulart, A.C.P.; Paiva, F.A. 1992. Incidence of blast (Pyricularia grisea) on different wheat (Triticum aestivum) cultivars under field conditions $=$ Incidência da brusone (Pyricularia grisea $)$ em diferentes cultivares de trigo (Triticum aestivum) em condições de campo. Fitopatologia Brasileira 17: 321-325 (in Portuguese).

Goulart, A.C.P.; Sousa, P.G.; Urashima, A.S. 2007. Damage to wheat caused by Pyricularia grisea infection. = Danos em trigo causados pela infecção de Pyricularia grisea. Summa Phytopathologica 33: 358-363 (in Portuguese).

Guével, M.H.; Menzies, J.G.; Bélanger, R.R. 2007. Effect of root and foliar applications of soluble silicon on powdery mildew control and growth of wheat plants. European Journal of Plant Pathology 119: 429-436.

Hoagland, D.R.; Arnon, D.I. 1950. The water culture method for growing plant without soil. California Agricultural Experiment Station Circular 347: 1-32.

Igarashi, S.; Utiamada, C.M.; Igarashi, I.C.; Kazuma, A.H.; Lopes, R.S. 1986. Pyricularia on wheat. 1. Occurrence of Pyricularia sp. in the state of Paraná. = Pyricularia em trigo. 1. Ocorrência de Pyricularia sp. no estado do Paraná Fitopatologia Brasileira 11: 351-352 (in Portuguese).

Koga, H.; Zeyen R.J.; Bushnell, W.R.; Ahlstrand, G.G. 1988. Hypersensitive cell death, autofluorescence, and insoluble silicon accumulation in barley leaf epidermal cells under attack by Erysiphe graminis f.sp. hordei. Physiological and Molecular Plant Pathology 32: 395-409.

Lattanzio, V.; Lattanzio, V.M.; Cardinali, A. 2006. Role of phenolics in the resistance mechanisms of plants against fungal pathogens and insects. Phytochemistry: Advances in Research 661: 23-67.

Ma, J.F.; Tamai, K.; Ichii, M.; Wu, G.F. 2002. A rice mutant defective in Si uptake. Plant Physiology 130: 2111-2117.

Nicholson, R.L.; Hammerchmidt, R. 1992. Phenolics compounds and their role in disease resistance. Annual Review of Phytopathology 30: 369-389.

Pagani, A.P.; Dianese, A.C.; Café Filho, A.C. 2014. Management of wheat blast with synthetic fungicides, partial resistance and silicate and phosphite minerals. Phytoparasitica DOI 10.1007/ s12600-014-0401-x.

Rémus-Borel, W.; Menzies, J.G.; Bélanger, R.R. 2005. Silicon induces antifungal compounds in powdery mildew-infected wheat. Physiological and Molecular Plant Pathology 66: 108115.
Resende, R.S.; Rodrigues, F.A.; Cavatte, P.C.; Martins, S.C.V.; Moreira, W.R.; Chaves, A.R.M.; Da Matta, F.M. 2012. Leaf gas exchange and oxidative stress in sorghum plants supplied with silicon and infected by Colletotrichum sublineolum. Phytopathology 102: 892-898.

Rodrigues, F.A.; Benhamou, N.; Datnoff, L.E.; Jones, J.B.; Bélanger, R.R. 2003. Ultrastructural and cytochemical aspects of silicon mediated rice blast resistance. Phytopathology 93: 535-546.

Rodrigues, F.A.; Jurick, W.M.; Datnoff, L.E.; Jones, J.B.; Rollins, J.A. 2005. Silicon influences cytological and molecular events in compatible and incompatible rice-Magnaporthe grisea interactions. Physiological and Molecular Plant Pathology 66: 144-159.

Rodrigues, F.A.; McNally, D.J.; Datnoff, L.E.; Jones, J.B.; Labbé, C.; Benhamou, N.; Menzies, J.G.; Bélanger, R.R. 2004. Silicon enhances the accumulation of diterpenoid phytoalexins in rice: a potential mechanism for blast resistance. Phytopathology 94: 177-183.

Shaner, G.; Finney, R.E. 1977. The effect of nitrogen fertilization on the expression of slow-mildewing resistance in knox wheat. Phytopathology 70: 1183-1186.

Shetty, R.; Jense, B.; Shetty, N.P.; Hansen, M.; Hansen, C.W.; Starkey, K.R.; Jorgensen, H.J.L. 2012. Silicon induced resistance against powdery mildew of roses caused by Podosphaera pannosa. Plant Pathology 61: 120-131.

Silva, I.T.; Rodrigues, F.A.; Oliveira, J.R.; Pereira, S.C.; Andrade, C.C.L.; Silveira, P.R.; Conceição, M.M. 2010. Wheat resistance to bacterial leaf streak mediated by silicon. Journal of Phytopathology 158: 253-262.

Sousa, R.S.; Rodrigues, F.A.; Schurt, D.A.; Souza, N.F.A.; Cruz, M.F.A. 2013. Cytological aspects of the infection process of Pyricularia oryzae on leaves of wheat plants supplied with silicon. Tropical Plant Pathology 38: 472-477.

Valette, C.; Andary, C.; Geiger, J.P.; Sarah, J.L.; Nicole, M. 1998. Histochemical and cytochemical investigations of phenols in roots of banana infected by the burrowing nematode Radopholus similis. Phytopathology 88: 1141-1148.

Xavier Filha, M.S.; Rodrigues, F.A.; Domiciano, G.P.; Oliveira, H.V.; Silveira, P.R.; Moreira, W.R. 2011. Wheat resistance to leaf blast mediated by silicon. Australasian Plant Pathology 40: 28-38.

Zadoks, J.C.; Chang, T.T.; Konzac, C.F. 1974. A decimal code for the growth stages of cereals. Weed Research 14: 415-421. 